\title{
Soil Aggregate Stability and Aggregate-Associated Carbon Fractions under Different Tillage Systems of Rice-Wheat Rotation in North India
}

\author{
Rajendra Kumar $^{1 *}$, R.K. Naresh ${ }^{1}$, N.C. Mahajan², S.K. Tomar ${ }^{3}$, \\ M. Sharath Chandra ${ }^{1}$ and Sunil Kumar ${ }^{4}$
}
${ }^{1}$ Department of Agronomy, Sardar Vallabhbhai Patel University of Agriculture \& Technology, Meerut, (UP), India
${ }^{2}$ Institute of Agricultural Sciences; Department of Agronomy, Banaras Hindu University, Varanasi (UP), India
${ }^{3}$ KVK Belipar, Gorakhpur, Narendra Dev University of Agriculture \& Technology, Kumarganj, Ayodhya, (UP), India
${ }^{4}$ Department of Agronomy, Chandra Shekhar Azad University of Agriculture \& Technology, Kanpur (UP), India

*Corresponding author:

\section{Keywords \\ Tillage systems, Aggregate- associated C, Soil organic carbon, Aggregate stability \\ Article Info \\ Accepted: \\ 10 May 2019 \\ Available Online: \\ 10 June 2019}

\section{A B S T R A C T}

The influences of tillage systems on soil carbon (C) stocks have been studied extensively, but the distribution of soil $\mathrm{C}$ within aggregate fractions is not well understood. This review study was to determine the influences of various tillage systems on soil aggregation and aggregate-associated C under rice-wheat rotation in North India. The NT and RT treatments significantly increased the proportion of macro-aggregate fractions ( $>2000$ and $250-2000 \mu \mathrm{m})$ compared with the MP-R and $\mathrm{MP}+\mathrm{R}$ treatments. Averaged across all depths, mean weight diameters of aggregates (MWD) in NT and RT were 47 and $20 \%$ higher than that in MP+R. The difference of total SOC stocks between NT and CT decreased with soil depth, confirming that the SOC benefits of NT are concentrated to the immediate topsoil still subject to direct seeding. The topsoil achieved maximum SOC stocks after about 10 years of NT. In surface soil, the maximum $(19.2 \%)$ and minimum $(8.9 \%)$ proportion of total aggregated carbon was retained with $>2 \mathrm{~mm}$ and $0.1-0.05 \mathrm{~mm}$ size fractions, respectively. DSR combined with zero tillage in wheat along with residue retention (T6) had the highest capability to hold the organic carbon in surface $(11.57 \mathrm{~g} \mathrm{~kg}$-1 soil with the highest stratification ratio of SOC (1.5). A considerable proportion of the total SOC was found to be captured by the macro-aggregates $(>2-$ $0.25 \mathrm{~mm}$ ) under both surface $(67.1 \%)$ and sub-surface layers $(66.7 \%)$ leaving rest amount in microaggregates and silt + clay sized particles. However increasing the quantity of $\mathrm{C}$ input could enhance soil C sequestration or reduce the rate of soil C loss, depending largely on the local soil and climate conditions. SOC can be best preserved by crop rotations with conservation tillage practices such as no or reduced tillage, and with additions of residues, chemical fertilizers and manure SOC change was significantly influenced by the crop residue retention rate and the edaphic variable of initial SOC content. Soil disturbance by tillage leads to destruction of the protective soil aggregate. This in turn exposes the labile $\mathrm{C}$ occluded in these aggregates to microbial breakdown. A higher amount of macro-aggregates along with greater accumulation of particulate organic $\mathrm{C}$ indicates the potential of conservation tillage for improving soil carbon over the long-term in rice-wheat rotation in North India. 


\section{Introduction}

Soil aggregation is important for the resistance of land surfaces to erosion, and it influences the ability of soils to remain productive. Modification of some soil attributes can be used to evaluate the soil physical condition, determining whether a certain soil management for crop production might improve its natural characteristics or the land capability. Soil aggregate distribution has been used as a conservation index for clayey Oxisols (Castro et al., 2002). Soil aggregation may be determined by mean weight diameter (MWD), geometric mean weight diameter (GMD) and aggregate stability (AS \%) index, which are obtained by fractioning the soil material into aggregate classes by wet sieving (Kemper and Chepil, 1965). These indices are sensitive to soil management practices and physical conditions of soil. Physical disturbance of soil structure (through tillage) has resulted in decreasing aggregate stability paralleled by a loss of soil organic matter (SOM) indicating a link between SOM and soil aggregate dynamics (Elliott, 1986; Six et al., 2000).

Over $60 \%$ of the world's carbon (C) is in soils about $40 \%$ and the atmosphere $20 \%$ (Sundquist, 1993). However, soil disturbance is redistributing the carbon and augmenting the atmospheric carbon pool. Tillage disrupts soil aggregates, which hasten soil organic matter (SOM) mineralization (Six et al., 1998). Jastrow et al., (1996) and Six et al., (1999) found that the majority of $\mathrm{C}$ in macro and micro aggregates is mineral- associated $\mathrm{C}$ formed during the decomposition of particulate organic matter (POM) and this fraction was responsible for long-term C sequestration. Kong et al., (2005) demonstrated that the relationship between organic $\mathrm{C}$ input and SOC sequestration was dominated by SOC increases within macro aggregates. However, macro aggregates are susceptible to tillage disruption (Elliott 1986; Cambardella and Elliott 1993). Disrupting macro aggregates exposes the micro aggregate $\mathrm{C}$ pool to decomposers, thereby increasing SOC mineralization (Bajracharya et al., 1997; Angers and Chenu 1997).

The level of physical protection provided by aggregates varies with soil management practices (Beare et al., 1994). Generally, there is more aggregate protection in no-till soils than in cultivated ones. Thus, the fates of SOM will de pend upon its decomposability and the persistence of aggregates, which relate to aggregate stability in water and resistance to other mechanical stresses (e.g. tillage). Several researchers found more macro aggregates in non-tillage or reduced tillage soils, as compared with conventional tillage soils (Carter, 1992; Six et al., 2000). Tisdall and Oades (1982) found that cultivation generally resulted in reduced macro aggregate number and stability but it had little effect on micro aggregate stability. As a consequence, the SOM that binds micro aggregates into larger macro aggregates was suggested to be the primary source of organic matter loss from soil cultivation practices (Elliott, 1986). Aggregation has a major effect on carbon cycling in soil. The initial unit of aggregation is called micro aggregate. The micro aggregates $(0.25 \mathrm{~mm})$ are bounded together by organic compounds of different origins to form macro aggregates $(0.25 \mathrm{~mm})$ Tisdall and Oades 1982. Soil aggregates are the secondary particles formed through the combination of mineral particles with organic and/or inorganic binding agents (Bronick and Lal, 2005). An aggregate consists of grouping of a number of primary particles into a secondary unit. The mechanisms of formation of these aggregates involve several factors such as vegetation, soil fauna, microorganisms, impact of cations, clay particle interactions in relation to moisture and temperature as well as organic matter and clay 
organic matter interactions (Baver and Gardner, 1972). Soil aggregation is an important factor for plant growth and directly affects water infiltration, the structure of the microbial community, soil biodiversity, soil biomass dynamics, nutrient adsorption and desorption, oxygen availability to the roots, and soil erosion (Denef et al., 2001; Franzluebbers, 2002; Six et al., 2004; Madari et al., 2005; Souza et al., 2009; An et al., 2010). Soil aggregation is directly related to soil management practices, such as the no-till system (NTS) (Bronick and Lal, 2005). The amount of SOM directly influences soil physical properties by enhancing aggregation as well as improving soil porosity, aeration, water infiltration, and water retention, which lead to a decrease in soil bulk density (Garcia and Rosolem, 2010). Traditionally, aggregate indices, such as mean weight diameter (MWD), mean geometric diameter (MGD), and the Aggregate Stability Index (ASI) have been used to assess soil aggregation (Madari et al., 2005). Managed Agricultural system can be an important sink for carbon storage. Enhancement of carbon storage may be achieved by adoption of best management practices such as zero tillage (ZT), cover crops, manuring and integrated nutrient management (INM), divers cropping system, mixed farming and Agroforestry (Lal, 2004). Conventional tillage reduces soil organic matter (SOM) and alters the distribution and stability of aggregates (Six et al., 1998; Anders et al., 2012). Zero tillage (ZT) can increase soil aggregation and carbon $(C)$ and nitrogen storage and improved soil physical, chemical and biological properties (Paustian et al., 1997; Anders et al., 2012; Hendrix et al., 1998).

\section{Distribution of soil aggregates with different sizes}

Ou et al., (2016) proposed that the proportion of the $>2 \mathrm{~mm}$ aggregate fraction in $\mathrm{NT}+\mathrm{S}$ was
$7.1 \%$ higher than that in NT-S in the 0.00$0.05 \mathrm{~m}$ layer. There was no significant difference in the total amount of all the aggregate fractions between $\mathrm{NT}+\mathrm{S}$ and NT-S in both the 0.05-0.20 and 0.20-0.30 m layers. Both NT+S and NT-S showed higher proportions of $>2 \mathrm{~mm}$ aggregate and lower proportions of $0.25 \mathrm{~mm}$ macro aggregate was significantly higher in $\mathrm{MP}+\mathrm{S}$ than in $\mathrm{MP}-\mathrm{S}$ in most cases, but the proportion of $<0.053 \mathrm{~mm}$ aggregate was $11.5-20.5 \%$ lower in $\mathrm{MP}+\mathrm{S}$ than MP-S for all the soil layers (Fig. 1a). Upendra et al., (2009) reported that No-till increased aggregate proportion compared with tilled treatments in the continuous spring wheat system in the 4.75 - to $2.00-\mathrm{mm}$ size class at 0 to $5 \mathrm{~cm}$ and in the $2.00-$ to $0.25-\mathrm{mm}$ size class at 5 to $20 \mathrm{~cm}$ (Fig. 1b). These resulted in subsequent increases in aggregate proportions in smaller aggregates. No-till increases soil aggregation by reducing soil disturbance and increasing soil organic matter content and the growth of fungi that bind the soil particles and micro-aggregates together (Beare et al., 1994 and Six et al., 2000). An increase in aggregate proportion was also observed in the fallow treatment in the 2.00to $0.25-\mathrm{mm}$ size class at 5 to $20 \mathrm{~cm}$, whose reasons were not known. Since aggregates $<0.84-\mathrm{mm}$ size class are prone to wind erosion in semiarid dry lands (Campbell et al., 1993), increased proportion of aggregates $>2.00-\mathrm{mm}$ size class in no-till compared with conventional till might reduce the risk of soil erosion. Aggregate proportion was greater in the 2.00 - to $0.25-\mathrm{mm}$ size class than in other size classes at both depths, suggesting that small macro-aggregates contributed the largest proportion of aggregates determined by dry sieving in dry land soils of the semiarid region. Similar observations were reported by Sainju (2006) and $\mathrm{Li}$ et al., (2007). Aggregate proportion was twice as much greater at 5 to 20 than at 0 to $5 \mathrm{~cm}$ in the 4.75 - to $2.00-\mathrm{mm}$ size class but was greater at 0 to 5 than at 5 to $20 \mathrm{~cm}$ in the 2.00 - 
to $0.25-\mathrm{mm}$ size class Schutter and Dick (2002) observed greater amount of soil in the 1.00 - to $0.25-\mathrm{mm}$ size class.

\section{Aggregate-associated soil organic carbon (SOC) concentration}

Ou et al., (2016) reported that in the 0.00-0.05 $\mathrm{m}$ layer, SOC concentration in macro aggregates showed the order of $\mathrm{NT}+\mathrm{S}>\mathrm{MP}+\mathrm{S}$ $=\mathrm{NT}-\mathrm{S}>\mathrm{MP}-\mathrm{S}$, whereas the NT system was superior to the MP system. However, the NT system significantly reduced the SOC concentration in the $2.00-0.25 \mathrm{~mm}$ fraction in the $0.05-0.20 \mathrm{~m}$ layer (Fig. 2a). A similar trend was observed in the $0.25-0.053 \mathrm{~mm}$ fraction in the $0.20-0.30 \mathrm{~m}$ layer. Across all the soil layers, there was no difference in the $<0.053 \mathrm{~mm}$ fraction between NT-S and MP-S, as well as between $\mathrm{NT}+\mathrm{S}$ and $\mathrm{MP}+\mathrm{S}$, indicating that the SOC concentration in Silt + Clay fraction. In average across the soil layers, the soil organic carbon concentration in the macro aggregates was increased by $13.5 \%$ in $\mathrm{MP}+\mathrm{S}, 4.4 \%$ in $\mathrm{ST}-\mathrm{S}$ and $19.3 \%$ in $\mathrm{NT}+\mathrm{S}$, and those the micro aggregates $(<0.25 \mathrm{~mm})$ were increased by $6.1 \%$ in $\mathrm{MP}+\mathrm{S}$ and $7.0 \%$ in NT+S compared to MP-S. For all the soil layers, the SOC concentration in all the aggregate size classes was increased with straw incorporation by $20.0,3.8$ and $5.7 \%$ under the MP system and 20.2, 6.3 and $8.8 \%$ under NT system.

Zheng et al., (2018) identified that the aggregate dimension varied with soil depth for different treatments and was more variable in the topsoil as compared to lower soil layers. Aggregate dimension for the spacing tillage (ST) and no tillage (NT) treatments were significantly lower than for the mould board plough (MP) and conventional tillage (CT) treatments at the $0-10 \mathrm{~cm}$ depth. This effect for the NT treatment disappeared with increased soil depth; however, the ST treatment still showed lower dimension for the $10-20$ and $20-30 \mathrm{~cm}$ depths. This variation dwindled at lower depths until $50-60 \mathrm{~cm}$, where there was no significant difference in dimension between ST, NT, and MP; however, dimension was significantly lower for the CT than for the ST and NT treatments (Fig. 2b).

\section{Distribution of water-stable aggregate- associated carbon $(\mathrm{C})$}

Macro- and micro-aggregate-associated C decreased with an increase in the soil depth, with a higher aggregate-associated $\mathrm{C}$ content in the topsoil compared to the sub-layer. Macro-aggregate-associated $\mathrm{C}$ content was highest in the ST treatment at the $0-10,10$ 20 , and $20-30 \mathrm{~cm}$ depths for all sizes of macro-aggregates, and at the 30-40 and 40$50 \mathrm{~cm}$ depths for macro-aggregates on average. For each depth $0-60 \mathrm{~cm}$, the microaggregate-associated $\mathrm{C}$ was highest in the ST treatment for water-stable aggregates of each size (Zheng et al., 2018). Chu et al., (2016) revealed that cropping system increased the stocks of $\mathrm{OC}$ and $\mathrm{N}$ in total soils at mean rates of $13.2 \mathrm{~g} \mathrm{OC} \mathrm{m}^{-2} \mathrm{yr}^{-1}$ and $0.8 \mathrm{~g} \mathrm{~N} \mathrm{~m}^{-2} \mathrm{yr}^{-1}$ at the $0-20 \mathrm{~cm}$ depth and of $2.4 \mathrm{~g} \mathrm{OC} \mathrm{m}^{-2} \mathrm{yr}^{-}$ ${ }^{1}$ and $0.4 \mathrm{~g} \mathrm{~N} \mathrm{~m}^{-2} \mathrm{yr}^{-1}$ at the $20-40 \mathrm{~cm}^{-1 e p t h}$. The stocks of $\mathrm{OC}$ and $\mathrm{N}$ in this system increased by 45 and 36\%, respectively, (with recovery rates of $31.1 \mathrm{OC} \mathrm{m}^{-2} \mathrm{yr}^{-1}$ and $2.4 \mathrm{~g} \mathrm{~N}$ $\mathrm{m}^{-2} \mathrm{yr}^{-1}$ ) at the $0-20 \mathrm{~cm}$ depth and by 5 and $6 \%$, (with recovery rates of $3.0 \mathrm{OC} \mathrm{m}^{-2} \mathrm{yr}^{-}$ ${ }^{1}$ and $0.03 \mathrm{~g} \mathrm{~N} \mathrm{~m}^{-2} \mathrm{yr}^{-1}$ ) at the $20-40 \mathrm{~cm}$ depth (Fig. 3a). Castro et al., (2004) also observed that the $0-5 \mathrm{~cm}$ depth, a higher percentage of water stable aggregates with a diameter $>4$ $\mathrm{mm}$ (56.8 67.9\%) were found in the conventional system compared with the notillage treatment (48.2-53.4\%). Choudhary et al., (2014) revealed that compared to conventional tillage, water stable macroaggregates in conservation tillage in wheat coupled with direct seeded rice (DSR) was increased by $50.13 \%$ and water stable micro- 
aggregates of the later decreased by $10.1 \%$ in surface soil.

Anders et al., (2010) also found that the total water stable aggregates (WSA), averaged across landscape position and sample depth and ranged from $150 \mathrm{~g} \mathrm{~kg}^{-1}$ in traditional tillage (TT) to $210 \mathrm{~g} \mathrm{~kg}^{-1}$ in no-tillage (NT). Total WSA was affected by tillage and sample depth. There were numerically greater total WSA in the 0 to $5-\mathrm{cm}$ soil layer than in the 5 to $10-\mathrm{cm}$ layer for the disc tillage (DT) and no-tillage treatments (Fig. 3b). This trend was opposite for the TT, where WSA were numerically lower in the 0 to $5-\mathrm{cm}$ soil layer. Water stable aggregate formation is closely related to soil order and the volume and composition of organic matter (Oades and Waters, 1991). Tillage has been shown to destroy aggregation via sorting the WSA in the tillage layer as well as exposing organic matter to increased microbial activity and decay (Kay, 1990; Roberson, 1991). There were no differences in total WSA in the 5 to $10-\mathrm{cm}$ layer of the DT and NT treatments and both soil layers in the TT. These results indicate that a mixing of soil layers, as was done in the TT, resulted in a reduced WSA content in both soil layers of the TT. Accumulation of WSA occurred primarily in the top 0 to $5-\mathrm{cm}$ soil layer of the DT and NT, where there was reduced or no soil disturbance from tillage. Cambardella and Elliott (1993); Beare et al., (1994); Mikha and Rice (2004) reported that traditional tillage reduced larger aggregates, with a still noticeable but reduced effect on smaller aggregates. Shaver et al., (2002) who found differences in macro- and micro aggregates across landscape positions with different cropping systems and attributed these differences to crop residue production and soil texture differences among sites. Management measures that include tillage and straw incorporation not only determine land productivity but also affect soil microbial biomass and activity by altering the temperature and humidity of the soil, the growth stage of the roots, and the quantity and quality of the crop residues, ultimately affecting the content and stability of soil aggregates. (Fig. 4a and 4b) showed that both the mean weight diameter (MWD) and aggregate stability (AS) of the soil aggregates were higher for the Rice Wheat zero tillage + Rice Wheat straw incorporation treatment than for the Rice Wheat zero tillage + No straw incorporation treatment Song et al., (2016). Results showed that the mean percentages of $>2 \mathrm{~mm}$ macroaggregates and water-stable macro-aggregates were increased by $12.77 \%$ and $43.21 \%$, respectively, for the treatment group of rice-wheat under zero tillage compared to Rice Wheat conventional tillage. In the $0-15 \mathrm{~cm}$ and $15-30 \mathrm{~cm}$ soil layers, the percentage of $2-0.25 \mathrm{~mm}$ waterstable macro-aggregates was increased by $25 \%$ and $40 \%$, respectively, for the Rice Wheat zero tillage treatment compared to the Rice Wheat conventional tillage treatment. Thus, compared to conventional tillage, zero tillage can reduce the turnover of macroaggregates in farmland and facilitate the enclosure of organic carbon in microaggregates, which enables micro-aggregates to preserve more physically protected organic carbon and form more macro-aggregates Causarano (2008). Moreover, results showed that zero tillage resulted in higher organic carbon storage in soil aggregates in the 0-15 $\mathrm{cm}$ soil layer than conventional tillage (Fig. $4 \mathrm{c}$ and $4 \mathrm{~d}$ ); primarily because conservation tillage reduces the damage to soil aggregates and increases the content and stability of associated organic carbon accordingly. The highest SOC concentration was found for the $0.25-0.106 \mathrm{~mm}$ micro-aggregates in the $0-15$ $\mathrm{cm}$ and $15-30 \mathrm{~cm}$ soil layers. Six et al., (2000) also found that $>2 \mathrm{~mm}$ aggregates had the highest SOC level compared to the other size classes of aggregates. Devine et al., (2014) reported that the $<53 \mathrm{~mm}$ aggregate 
fraction had lower total SOC concentrations when expressed on a sand-free basis. Under FS from $0-15 \mathrm{~cm}$, there were no other significant differences among the size classes $>53 \mathrm{~mm}$ (Fig. 5a and 5b). Under no tillage (NT), in the upper $15 \mathrm{~cm}$ both the large macro-aggregates and the $<53 \mathrm{~mm}$ fractions were SOC depleted relative to the small macro-aggregates (250-2000 mm) and microaggregates. This was similar under conventional tillage (CT) from $0-5 \mathrm{~cm}$ where the small macro-aggregates $(250-2000 \mathrm{~mm})$ were significantly elevated in total SOC. Under CT from 5-15 cm, both the small macro-aggregates and micro-aggregates were elevated in total SOC compared to the large macro-aggregates but only the small macroaggregates were significantly elevated compared to the large macro-aggregates. From 15-28 cm, the large macro-aggregates were the most carbon rich under all land uses, having significantly greater total SOC and fine $\mathrm{C}$ concentrations compared to the $<250$ $\mathrm{mm}$ size fractions.

Beare et al., (1994) observed the highest C concentrations in the large NT microaggregates $(106-250 \mathrm{~mm})$ compared to the macro-aggregates from $0-5 \mathrm{~cm}$ and speculated that this was due to formation of micro-aggregates around decomposing residues in stable macro-aggregates, followed by their release upon macro aggregate breakdown.

Chen et al., (2009) revealed that the mean weight diameter (MWD) and geometric mean diameter (GMD) of soil aggregates were significantly influenced by tillage (Fig. 6a). At $0-15 \mathrm{~cm}$, MWDs and GMDs were significantly lower under conventional tillage (CT) than shallow tillage (ST) or NT, whereas the differences between ST and NT were not significant (Fig. 6a). However, MWDs and GMDs decreased with increase in soil depth for all tillage treatments (Fig. 6b). At both depths, the content of large macroaggregates (>2 mm) was very low (around $1 \%$ of the soil weight) (Fig. 6b). Small macroaggregates (2$0.25 \mathrm{~mm}$ ) represented the greatest portions $(52-70 \%$ of whole soil) in all treatments at both $0-15$ and $15-30 \mathrm{~cm}$. At $0-15 \mathrm{~cm}, \mathrm{CT}$ contained significantly less small macroaggregates $(2-0.25 \mathrm{~mm})$ than ST or NT, which were not different from each other (Fig. 6a). Tillage significantly decreased MWD and GWD at both depths, although the differences were not always significant at the subsurface layer (Fig. 6b). Zotarelli et al., (2005) also found that the MWD of the aggregates was on average $0.5 \mathrm{~mm}$ greater under NT compared with CT in the $0-5-\mathrm{cm}$ depth interval. Zibilske and Bradford (2007) showed that plow tillage had significantly lower MWDs than no-tillage and ridge tillage at both $0-5-$ and 10-15-cm depths in sandy clay loam soil.

Kumar, M et al., (2011) revealed that in 0$5 \mathrm{~cm}$ layer, ZT had significantly higher SOC of 7.37 and $7.86 \mathrm{~g} \mathrm{~kg}^{-1}$ in $\mathrm{T}_{5}$ and $\mathrm{T}_{6}$, respectively than those of 5.81 and $6.14 \mathrm{~g}$ $\mathrm{kg}^{-1}$ in conventional tillage treatments $\mathrm{T}_{1}$ and $\mathrm{T}_{2}$, respectively (Fig. 7a). This indicated a greater potential for $\mathrm{C}$ accumulation with $\mathrm{ZT}$ likely to be associated with factors such as (a) a reduction in soil disturbance, (b) undisturbed left -over stubbles on the surface, and their slow decomposition leading to cooler soil temperature, and (c) increased soil water retention. All of these favored the formation and stabilization of soil aggregates and their associated organic $\mathrm{C}$, which has been protected from rapid breakdown and decomposition. Like rice, soil Carbon at wheat harvest was higher in ZT than conventional tillage. In addition, raised-bed planting also resulted in higher $\mathrm{C}$ (6.79 and $6.83 \mathrm{~g} \mathrm{~kg}^{-1}$ in $\mathrm{T}_{3}$ and $\mathrm{T}_{4}$, respectively) than conventional $\mathrm{T}_{1}$ and $\mathrm{T} 2$ (5.68 and $5.93 \mathrm{~g} \mathrm{~kg}^{-1}$ in $\mathrm{T}_{1}$ and $\mathrm{T}_{2}$, respectively). This observation together with the better macro-aggregate 
status revealed that the raised-bed system presumably also preserved soil structure. It is interesting to note that though $\mathrm{C}$ content was generally higher at $0-$ to $5-\mathrm{cm}$ than that at 5to $10-\mathrm{cm}$ depth, the difference between two layers was almost double in ZT than that of conventional tillage.

Kumari M et al., (2011) also found that tillage induced changes in the intra-aggregate POM$\mathrm{C}$ content was distinguishable at $0-$ to $5-\mathrm{cm}$ depth only (Fig. 7b). On average, the iPOM C content in soil was higher at wheat than at rice harvest, and accumulated in greater portion as fine $(0.053-0.25 \mathrm{~mm})$ than the coarse $(0.25-2$ $\mathrm{mm})$ fraction. A significantly higher particulate-C fraction was recorded in the zero-till systems ( $\mathrm{T}_{5}$ and $\left.\mathrm{T}_{6}\right)$, and was associated more with the fine fractions $(20$ $30 \%$ higher than under conventional-tillage $\mathrm{T}_{1}$ and $\mathrm{T}_{2}$ ). The iPOM-C is physically better protected than other POM-C fractions.in soil. The raised-bed systems $\left(\mathrm{T}_{3}\right.$ and $\left.\mathrm{T}_{4}\right)$ indicated higher soil $\mathrm{C}$ content associated with macroaggregates compared with conventional treatments $\left(\mathrm{T}_{1}\right.$ and $\left.\mathrm{T}_{2}\right)$, but the iPOM-C showed no difference. Furthermore, the higher amounts of macro-aggregates together with increased iPOM-C indicate the potential of ZT for improving the soil $\mathrm{C}$ stocks.

Zhang-liu et al., (2013) showed that NT and RT treatments significantly increased the proportion of macro-aggregate fractions $(>2$ 000 and 250-2 $000 \mu \mathrm{m}$ ) compared with the $\mathrm{MP}-\mathrm{R}$ and $\mathrm{MP}+\mathrm{R}$ treatments. Averaged across all depths, mean weight diameters of aggregates (MWD) in NT and RT were 47 and $20 \%$ higher than that in MP+R. The concentration of bulk soil organic $\mathrm{C}$ was positively correlated with MWD and macroaggregate fraction in the $0-5 \mathrm{~cm}$ depth. In the 0-20 cm depth, comparing with $\mathrm{MP}+\mathrm{R}$, total $\mathrm{C}$ occluded in the $>2000 \mu \mathrm{m}$ fraction was increased by 9 and 6\% under NT and RT, respectively. Mazumdar et al., (2015) also found that the Concentration of $\mathrm{C}$ was higher in macro-aggregates as compared to microaggregates. Irrespective of treatments, C concentration was highest in 1-2 mm followed by $0.5-1 \mathrm{~mm}$ size of macroaggregates and the concentration decreased as the aggregates became smaller in size (Fig. 8a). Incorporation of organic manures induces decomposition of organic matter where roots hyphae and polysaccharides bind mineral particles into micro-aggregates and then these micro-aggregates bind to form $\mathrm{C}$ rich macro=aggregates (Fig. 8a). Zhao et al., (2018) revealed that the straw return treatments, particularly MR-WR, increased the proportions of $\mathrm{mSOM}$ and fine iPOM within small macro-aggregates and microaggregates, especially in the $0-20 \mathrm{~cm}$ layer (Fig. 8b). The carbon content of iPOM was much lower at $20-40 \mathrm{~cm}$ than at $0-20 \mathrm{~cm}$ (Fig. 8b).

Naresh et al., (2017) reported that the macroaggregates are less stable than microaggregates, and therefore more susceptible to the disruption forces of tillage. The influence of tillage on aggregate $\mathrm{C}$ and $\mathrm{Nt}$ content is shown in (Fig. 8c). At $0-15 \mathrm{~cm}$, tillage effect was confined to the $2-0.25 \mathrm{~mm}$ size fraction, in which the conservation tillage treatments contained significantly higher SOC contents than CT, ST had significantly higher $\mathrm{Nt}$ contents than CT, and NT tended to have higher $\mathrm{Nt}$ contents than CT (Fig. 8c). No significant differences were detected in SOC and $\mathrm{Nt}$ contents in the $0.25-0.05 \mathrm{~mm}$ and $<0.05 \mathrm{~mm}$ classes among all treatments (Fig. $8 \mathrm{c})$. The highest SOC and Nt contents were found in the 2-0.25 size fraction. Data from the $15-$ to $30-\mathrm{cm}$ samples show generally diminished effect of tillage treatments (Fig. 7c). Soil organic $\mathrm{C}$ and $\mathrm{Nt}$ contents in the aggregate-size fractions generally decreased with increase in soil depth for all treatments (Fig. 8c). Chen et al., (2009) reported that reduced tillage (RT) contained $7.3 \%$ more 
SOC and $7.9 \%$ more $\mathrm{N}$ stocks than plough tillage (PT) in the 0-20-cm depth, respectively, and estimated that $\mathrm{RT}$ accumulate an average $0.32 \mathrm{Mg} \mathrm{C} \mathrm{ha}^{-1} \mathrm{yr}^{-1}$ and $0.033 \mathrm{Mg} \mathrm{N} \mathrm{ha}^{-1} \mathrm{yr}^{-1}$ more than PT over an average period of 11 years, respectively.

Gu et al., (2016) bserved that the soil under mulching treatments ST and GT had significantly higher LOC, DOC, POC and EOC concentrations in the surface $0 \pm 40 \mathrm{~cm}$ layer than those with no mulching treatment (Fig. 9), probably attributable to the inputs of straw, root and its sections. Concentrations of labile $\mathrm{C}$ fractions in all treatments tended to decrease with soil depth (Fig. 9). Liu et al., (2012), this could have been due to the fact that concentrations of total carbon and labile $\mathrm{C}$ fractions in all treatments showed seasonal dynamic change. LOC is a short-term repository of soil nutrients and its main constituent is freestate carbon (Post and Kwon, 2000).

Naresh et al., (2017) reported that the WSC was found to be $5.48 \%$ higher in surface soil than in sub-surface soil (Table 1). In both the depths, T6 treatment had the highest WSC as compared to the other treatments studied. Compared to CT, FIRB and ZT coupled with 6tha ${ }^{-1}$ CR increased $35.6 \%$ WSC in surface soil and $33.1 \%$ in sub surface soil. Among all the treatments, $\mathrm{T}_{6}$ had significantly higher (19.73\%) proportion of WSC than the other treatments compared. Irrespective of tillage practices, residue retention resulted in $22.56 \%$ and $25.61 \%$ higher WSC as compared to the non-residue treatments in surface and subsurface soil, respectively. The microbial biomass carbon (MBC) is an important component of the SOM that regulates the transformation and storage of nutrients. The soil MBC regulates all SOM transformations and is considered to be the chief component of the active SOM pool. It is evident that the MBC contents in both surface and sub-surface soil were significantly higher in plots receiving 100\% RDN as CF+ VC @ 5tha ${ }^{-1}$ $\left(\mathrm{F}_{5}\right)$ and $75 \% \mathrm{RDN}$ as $\mathrm{CF}+\mathrm{VC} @ 5$ tha $^{-1}\left(\mathrm{~F}_{4}\right)$ treated plots compared to $100 \% \mathrm{RDN}$ as $\mathrm{CF}$ $\left(F_{2}\right)$ fertilizer and unfertilized control plots (Table 1). The values of MBC in surface soil varied from $116.8 \mathrm{mgkg}^{-1}$ in unfertilized control plot to $424.1 \mathrm{mgkg}^{-1}$ in integrated nutrient use of $100 \%$ RDN as CF+ VC @ 5 tha $^{-1}$ plots, respectively; while it varied from $106.6 \mathrm{mgkg}^{-1}$ (control) to $324.9 \mathrm{mgkg}^{-1}$ (100\% RDN as CF+ VC @ 5tha $\left.{ }^{-1} \mathrm{~F}_{5}\right)$ in subsurface $(15-30 \mathrm{~cm})$ soil layer. The values of MBC increased by 72.5 and $58.4 \%$ under $100 \%$ RDN as $\mathrm{CF}+\mathrm{VC} @ 5$ tha $^{-1}\left(\mathrm{~F}_{5}\right)$ and 75\% RDN as CF+ VC @ 5tha ${ }^{-1}\left(\mathrm{~F}_{4}\right)$ treatment in surface soil over control. The values of LFC in surface soil $(0-15 \mathrm{~cm})$ were 81.3 , 95.7, 107.8, 128.8, 155.2, 177.8 and 52.7 $\mathrm{mgkg}^{-1}$ in ZT and FIRB without residue retention, ZT and FIRB with 4 and 6 tha $^{-1}$ residue retention and $\mathrm{CT}$ treatments, respectively (Table 1).

Ou et al., (2016) reported that the tillage systems obviously affected the distribution of soil aggregates with different sizes (Fig. 10a). The proportion of the $>2 \mathrm{~mm}$ aggregate fraction in $\mathrm{NT}+\mathrm{S}$ was $7.1 \%$ higher than that in NT-S in the 0.00-0.05 m layer. There was no significant difference in the total amount of all the aggregate fractions between $\mathrm{NT}+\mathrm{S}$ and NT-S in both the 0.05-0.20 and 0.20-0.30 $m$ layers. NT+S and NT-S showed higher proportions of $>2 \mathrm{~mm}$ aggregate and lower proportions of $<0.053 \mathrm{~mm}$ aggregate compared to the MP system for the $0.00-0.20$ $\mathrm{m}$ layer. The proportion of $>0.25 \mathrm{~mm}$ macroaggregate was significantly higher in $\mathrm{MP}+\mathrm{S}$ than in MP-S in most cases, but the proportion of $<0.053 \mathrm{~mm}$ aggregate was 11.5 $20.5 \%$ lower in MP+S than in MP-S for all the soil layers (Fig. 10a). However, NT system did affect the SOC stock distribution in the soil profile but not the total quantity. Tillage regimes obviously influenced soil 
aggregation distribution in the soil profile. In the upper 0.00-0.05 and 0.05-0.20 m layers, the NT system improved the formation level of the $>2 \mathrm{~mm}$ aggregate but reduced the formation level of $<0.053 \mathrm{~mm}$ aggregates, compared to the MP system, suggesting that mechanical operation reduced large-macroaggregate formation and disrupted soil macroaggregates into individual particles (Jiang et al., 2011). The aggregate-associated SOC concentration in different soil layers was influenced by tillage systems (Fig. 10b). In the 0.00-0.05 m layer, SOC concentration in macro-aggregates showed the order of $\mathrm{NT}+\mathrm{S}>\mathrm{MP}+\mathrm{S}=\mathrm{NT}-\mathrm{S}>\mathrm{MP}-\mathrm{S}$, whereas the NT system was superior to the MP system. However, the NT system significantly reduced the SOC concentration in the 2.00$0.25 \mathrm{~mm}$ fraction in the $0.05-0.20 \mathrm{~m}$ layer. A similar trend was observed in the $0.25-0.053$ $\mathrm{mm}$ fraction in the $0.20-0.30 \mathrm{~m}$ layer.

Across all the soil layers, there was no difference in the $<0.053 \mathrm{~mm}$ fraction between NT-S and MP-S, as well as between NT+S and $\mathrm{MP}+\mathrm{S}$, indicating that the NT system did not affect the SOC concentration in the silt + clay fraction. In average across the soil layers, the SOC concentration in the macro-aggregate was increased by $13.5 \%$ in $\mathrm{MP}+\mathrm{S}, 4.4 \%$ in NT-S and $19.3 \%$ in NT+S, and those in the micro-aggregate $(<0.25 \mathrm{~mm})$ were increased by $6.1 \%$ in $\mathrm{MP}+\mathrm{S}$ and $7.0 \%$ in $\mathrm{NT}+\mathrm{S}$ compared to MP-S.

For all the soil layers, the SOC concentration in all the aggregate size classes was increased with straw incorporation, by 20.0, 3.8 and 5.7 $\%$ under the MP system, and 20.2, 6.3 and 8.8 $\%$ under the NT system (Fig. 10b). The higher proportion of $>2 \mathrm{~mm}$ aggregates and lower proportion of $<0.053 \mathrm{~mm}$ aggregates under NT systems might be the result of the higher soil hydrophobicity, low intensity of wetting and drying cycles, higher soil $\mathrm{C}$ concentration or the physical and chemical characteristics of large macro-aggregates making them more resistant to breaking up (Vogelmann et al., 2013). Naresh et al., (2018) reported that conservation tillage practices significantly influenced the total soil carbon (TC), Total inorganic carbon (TIC), total soil organic carbon (SOC) and oxidizable organic carbon (OC) content of the surface $(0-15 \mathrm{~cm})$ soil (Table 2).

Wide raised beds transplanted rice and zero till wheat with $100 \%\left(\mathrm{~T}_{9}\right)$ or with $50 \%$ residue management $\left(\mathrm{T}_{8}\right)$ showed significantly higher TC, SOC content of 11.93 and $10.73 \mathrm{~g} \mathrm{~kg}^{-1}$, respectively in $\mathrm{T} 9$ and 10.98 and $9.38 \mathrm{~g} \mathrm{~kg}^{-1}$, respectively in $\mathrm{T}_{8}$ (Table 2 ) as compared to the other treatments. Irrespective of residue incorporation/retention, wide raised beds with zero till wheat enhanced $53.6 \%, 33.3 \%$, $38.7 \%$ and $41.9 \%$ of TC, TIC, SOC and OC, respectively, in surface soil as compared to conventional tillage with transplanted rice cultivation. Simultaneously, residue retention caused an increment of $6.4 \%, 7.4 \%, 8.7 \%$ and $10.6 \%$ in TC, TIC, SOC and OC, respectively over the treatments without residue management. There was no significant effect of conservation practices on different forms of carbon under sub-surface $(15-30 \mathrm{~cm})$ soil Table 2). Stewart et al., (2008) stated that the $\mathrm{C}$ sequestration capacity of a soil is determined mainly by the protection of $\mathrm{C}$ in the aggregates. Soil C stocks change with tillage and management practices (Srinivasarao et al., 2012).

Deng et al., (2016) revealed that soil OC stocks and OC sequestration in the surface 20 $\mathrm{cm}$ of soils were significantly increased along with the vegetation restoration since land-use change (Fig. 11a).

Among the different restoration stages, the rates showed non-significant differences (Fig. 11a), but the values were higher in the early stage $(<30$ year) of vegetation restoration 
than the latter (Fig. 11a). This is probably because: (1) vegetation restoration facilitated SOC accumulation from biomass input (Tang et al., 2010).

Vegetation biomass resulting from aboveground leaf litter and belowground roots is the main source of organic matter input into the soil (Zhao et al., 2015) (2) vegetation restoration probably contributed to the formation of stable soil aggregates (An et al.,
2010) thus facilitating physical protection of SOC within aggregates (Blanco-Canqui and Lal, 2004) and (3) the lower SOC concentrations of farmland under conventional tillage may be due to OC loss resulting from soil erosion, higher organic matter decomposition associated with aggregate disruption and/or OC input reduction caused by continuous removal of crop residues (Saha et al., 2014).

Table.1 Concentrations of different soil organic matter carbon fractions fPOM and cPOM at different soil depths as affected by tillage and nutrient management to the continuous RW cropping system (Naresh et al., 2017)

\begin{tabular}{|c|c|c|c|c|c|c|c|c|c|c|}
\hline \multirow[b]{2}{*}{ Treatments } & \multicolumn{5}{|c|}{$0-15 \mathrm{~cm}$ layer } & \multicolumn{5}{|c|}{$15-30 \mathrm{~cm}$ layer } \\
\hline & WSC $\left(\mathrm{mgkg}^{-1}\right)$ & $\operatorname{MBC}\left(\mathbf{m g k g}^{-1}\right)$ & $\begin{array}{c}\text { LFC } \\
\left(\mathrm{mgkg}^{-1}\right)\end{array}$ & $\begin{array}{c}{ }_{\mathrm{f}}^{\mathrm{POM}} \\
\left(\mathrm{g} \mathrm{Ckg}^{-1}\right)\end{array}$ & $\begin{array}{c}{ }_{\mathrm{c}}^{\mathrm{POM}} \\
\left(\mathrm{g} \mathrm{Ckg}^{-1}\right)\end{array}$ & WSC $\left(\mathrm{mgkg}^{-1}\right)$ & $\operatorname{MBC}\left(\mathrm{mgkg}^{-1}\right)$ & LFC $\left(\mathbf{m g k g}^{-1}\right)$ & $\begin{array}{c}{ }_{\mathrm{f}}^{\mathrm{POM}} \\
\left(\mathrm{g} \mathrm{Ckg}^{-1}\right)\end{array}$ & $\begin{array}{c}{ }_{\mathrm{c}}^{\mathrm{POM}} \\
\left(\mathrm{g} \mathrm{Ckg}^{-1}\right)\end{array}$ \\
\hline \multicolumn{11}{|c|}{ Tillage crop residue practices } \\
\hline $\mathrm{T}_{1}$ & $16.9^{\mathrm{d}}$ & $311.4^{\mathrm{c}}$ & $81.3^{\mathrm{d}}$ & $0.44^{\mathrm{d}}$ & $0.92^{\text {cd }}$ & $15.7^{\mathrm{d}}$ & $193.9^{\mathrm{cd}}$ & $65.1^{\mathrm{d}}$ & $0.32^{\text {cd }}$ & $0.58^{\mathrm{bc}}$ \\
\hline $\mathrm{T}_{2}$ & $18.9^{\mathrm{c}}$ & $345.2^{\mathrm{bc}}$ & $107.8^{\mathrm{bc}}$ & $0.62^{\text {bcd }}$ & $1.82^{\mathrm{bc}}$ & $17.8^{\mathrm{cd}}$ & $219.8^{\mathrm{c}}$ & $94.1^{\text {bc }}$ & $0.55^{\mathrm{de}}$ & $1.31^{\mathrm{bcd}}$ \\
\hline $\mathrm{T}_{3}$ & $20.8^{\mathrm{ab}}$ & $481.7^{\mathrm{a}}$ & $155.2^{\mathrm{a}}$ & $0.88^{\mathrm{ab}}$ & $2.54^{\mathrm{a}}$ & $19.6^{\text {bc }}$ & $294.8^{\mathrm{ab}}$ & $132.6^{\mathrm{a}}$ & $0.83^{\mathrm{c}}$ & $1.93^{\mathrm{a}}$ \\
\hline $\mathrm{T}_{4}$ & $18.7^{\mathrm{d}}$ & $306.5^{\mathrm{c}}$ & $95.7^{\mathrm{c}}$ & $0.53^{\text {cd }}$ & $1.03^{\mathrm{d}}$ & $17.6^{\mathrm{cd}}$ & $187.5^{\mathrm{cd}}$ & $87.6^{\mathrm{c}}$ & $0.35^{\mathrm{bc}}$ & $0.94^{\mathrm{ab}}$ \\
\hline $\mathrm{T}_{5}$ & $21.4^{\mathrm{bc}}$ & $398.6^{\mathrm{b}}$ & $128.8^{\mathrm{b}}$ & $0.86^{\mathrm{bc}}$ & $2.21^{\mathrm{ab}}$ & $20.3^{\mathrm{ab}}$ & $240.9^{\mathrm{bc}}$ & $102.9^{\mathrm{b}}$ & $0.72 a$ & $1.64^{\mathrm{a}}$ \\
\hline$T_{6}$ & $23.2^{\mathrm{a}}$ & $535.8^{\mathrm{a}}$ & $177.8^{\mathrm{a}}$ & $1.30^{\mathrm{a}}$ & $2.38^{\mathrm{ab}}$ & $21.6^{\mathrm{a}}$ & $361.8^{\mathrm{a}}$ & $141.2^{\mathrm{a}}$ & $1.19^{\mathrm{e}}$ & $1.89^{\mathrm{cd}}$ \\
\hline $\mathrm{T}_{7}$ & $14.2^{\mathrm{e}}$ & $266.7^{\mathrm{c}}$ & $52.7^{\mathrm{e}}$ & $0.38^{\mathrm{d}}$ & $0.94^{\mathrm{d}}$ & $13.8^{\mathrm{e}}$ & $145.9^{\mathrm{d}}$ & $49.8^{\mathrm{e}}$ & $0.26^{\mathrm{f}}$ & $0.61^{\mathrm{d}}$ \\
\hline \multicolumn{11}{|c|}{ Fertilizer Management Practices } \\
\hline$F_{1}$ & $21.9^{\mathrm{e}}$ & $116.8^{c}$ & $89.2^{\mathrm{c}}$ & $0.41^{d}$ & $0.64^{\mathrm{d}}$ & $15.1^{\mathrm{e}}$ & $106.6^{\mathrm{d}}$ & $47.9^{f}$ & 0.28 & $0.48^{\mathrm{d}}$ \\
\hline $\mathrm{F}_{2}$ & $28.4^{d}$ & $189.2^{\mathrm{c}}$ & $123.5^{b c}$ & $0.60^{\text {cd }}$ & $0.93^{d}$ & $18.8^{d}$ & $166.8^{\mathrm{cd}}$ & $66.7^{e}$ & 0.45 & 0.59 \\
\hline $\mathrm{F}_{3}$ & $29.2^{\mathrm{cd}}$ & $239.9^{\mathrm{bc}}$ & $146.4^{c}$ & $0.71^{\text {cd }}$ & $1.52^{\mathrm{cd}}$ & $20.2^{\mathrm{cd}}$ & $196.8^{b c}$ & $85.9^{d}$ & 0.52 & $0.74^{\text {cd }}$ \\
\hline $\mathrm{F}_{4}$ & $29.8^{c}$ & $280.7 b$ & $160.5^{b}$ & $1.33^{\mathrm{ab}}$ & $2.81^{\mathrm{ab}}$ & $21.9^{b c}$ & $219.9^{b c}$ & $103.2^{\mathrm{bc}}$ & 0.72 & $1.64^{\mathrm{ab}}$ \\
\hline $\mathrm{F}_{5}$ & $32.5^{\mathrm{a}}$ & $424.1^{\mathrm{a}}$ & $183.9^{\mathrm{a}}$ & $1.89^{\mathrm{a}}$ & $3.78^{\mathrm{a}}$ & $26.4^{\mathrm{a}}$ & $324.9^{\mathrm{a}}$ & $152.9^{\mathrm{a}}$ & 0.92 & $2.34^{\mathrm{a}}$ \\
\hline $\mathrm{F}_{6}$ & 28.9 & 210.3 & $133.2^{\mathrm{c}}$ & 0.66 & 1.19 & 19.8 & 178.2 & 76.4 & 0.51 & 0.63 \\
\hline
\end{tabular}

$* *$ Different letters within columns are significantly different at P=0.05 according to Duncan Multiple Range Test (DMRT) for separation of means. WSC $=$ water soluble carbon, $\mathrm{MBC}=$ microbial biomass carbon, $\mathrm{LFC}=$ labile fraction carbon, $\mathrm{cPOM}=$ coarse particulate organic carbon, $\mathrm{PPOM}=$ fine particulate organic carbon

Table.2 Effect of tillage and residue management practices on distribution of different forms of carbon in soil (Naresh et al., 2018)

\begin{tabular}{|c|c|c|c|c|c|c|c|c|}
\hline \multirow{2}{*}{ Treatments } & \multicolumn{2}{|c|}{ TC $\left(\mathrm{g} \mathrm{kg}^{-1}\right)$} & \multicolumn{2}{|c|}{ TIC $\left(\mathrm{g} \mathrm{kg}^{-1}\right)$} & \multicolumn{2}{|c|}{ SOC $\left(\mathrm{g} \mathrm{kg}^{-1}\right)$} & \multicolumn{2}{|c|}{$O C\left(g_{~ k g^{-1}}\right)$} \\
\hline & $0-15 \mathrm{~cm}$ & $15-30 \mathrm{~cm}$ & $0-15 \mathrm{~cm}$ & $15-30 \mathrm{~cm}$ & $0-15 \mathrm{~cm}$ & $15-30 \mathrm{~cm}$ & $0-15 \mathrm{~cm}$ & $15-30 \mathrm{~cm}$ \\
\hline $\mathrm{T}_{1}$ & $8.42 \mathrm{ef} \pm 0.01$ & $7.81 \mathrm{~d} \pm 0.01$ & $0.45 b c \pm 0.05$ & $0.30 c \pm 0.03$ & $6.67 \mathrm{de} \pm 0.02$ & $8.36 c \pm 0.02$ & $5.43 \mathrm{de}=0.03$ & \\
\hline $\mathrm{T}_{2}$ & & 8.57 & 0. & & 1 & & 7.56 & \\
\hline $\mathrm{T}_{3}$ & & 8.9 & 0.60 & & 10 & & 7.78 & \\
\hline $\mathrm{T}_{4}$ & & & & & & & & \\
\hline $\mathrm{T}_{5}$ & & & & & & & & \\
\hline $\mathrm{T}_{6}$ & 4 & 8.2 & 0.60 & & 7.0 & 9.0 & 6.77 & 5.5 \\
\hline $\mathrm{T}_{7}$ & \pm 0.02 & $8.10 \mathrm{c}$ & $0.60 \mathrm{abc} \pm 0.06$ & 0.45 & $6.79 \mathrm{de} \pm 0.09$ & 8.6 & $5.58 \mathrm{c}$ & 5.58 \\
\hline $\mathrm{T}_{8}$ & $10.98 \mathrm{ab} \pm 0.03$ & $9.24 \mathrm{a} \pm 0.01$ & $0.75 \mathrm{ab} \pm 0.08$ & $0.60 \mathrm{~b} \pm 0.06$ & $9.38 \mathrm{a} \pm 0.06$ & $9.31 \mathrm{ab} \pm 0.02$ & 7.59abc \pm 0.08 & $6.37 \mathrm{~b} \pm 0.03$ \\
\hline $\mathrm{T}_{9}$ & $11.93 a \pm 0.05$ & 10.4 & $0.90 \mathrm{a} \pm 0.09$ & 0.09 & $10.73 a \pm 0.02$ & 0.01 & $8.41 \mathrm{a} \pm 0.07$ & 0.04 \\
\hline$T_{10}$ & $6.39 \mathrm{f} \pm 0.01$ & $6.12 \mathrm{e} \pm 0.06$ & $0.30 c \pm 0.03$ & $0.22 c \pm 0.03$ & $4.16 \mathrm{e} \pm 0.02$ & $6.82 \mathrm{~d} \pm 0.03$ & $3.53 \mathrm{e} \pm 0.01$ & 0.01 \\
\hline
\end{tabular}

$\mathrm{TC}=$ Total carbon; $\mathrm{TIC}=$ Total inorganic carbon; $\mathrm{SOC}=$ Total soil organic carbon; $\mathrm{OC}=$ Oxidizable organic carbon Different small letters within the same column show the significant difference at $P=0.05$ according to Duncan Multiple Range Test for sevaration of mean. 
Fig.1a\&b (a): Distribution (\%) of water-stable aggregates with different sizes in different soil layers as influenced by tillage treatments [Source: Ou et al., 2016 and Effects of tillage and cropping sequence on dry land soil aggregate-size distribution at the 0 - to 5- and 5- to 20-cm depths [ Source: Upendra et al., 2009]

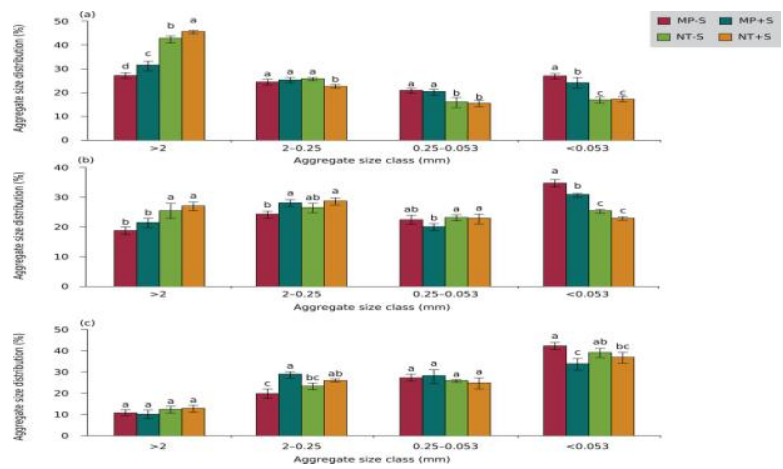

(a)

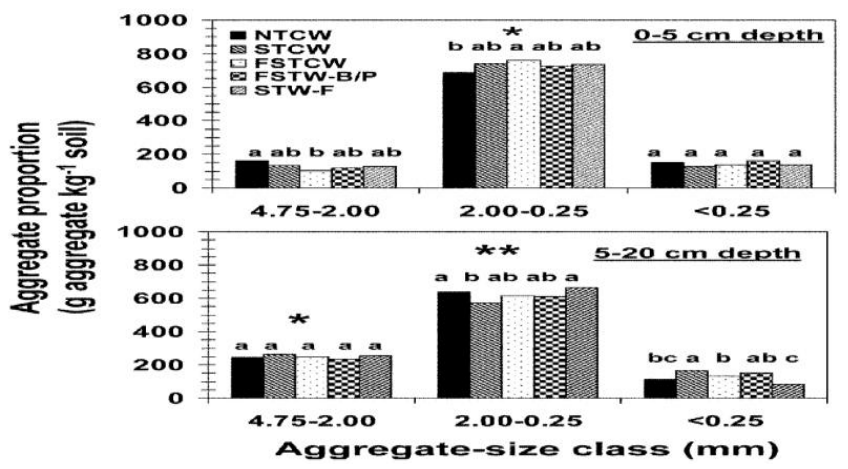

(b)

Fig.2a\&b Aggregate-associated SOC concentration in different layer intervals as influenced by tillage treatments [Source: Ou et al., 2016] and Effect of tillage on fractal dimension (D) of water-stable aggregates [Source: Zheng et al., 2018]

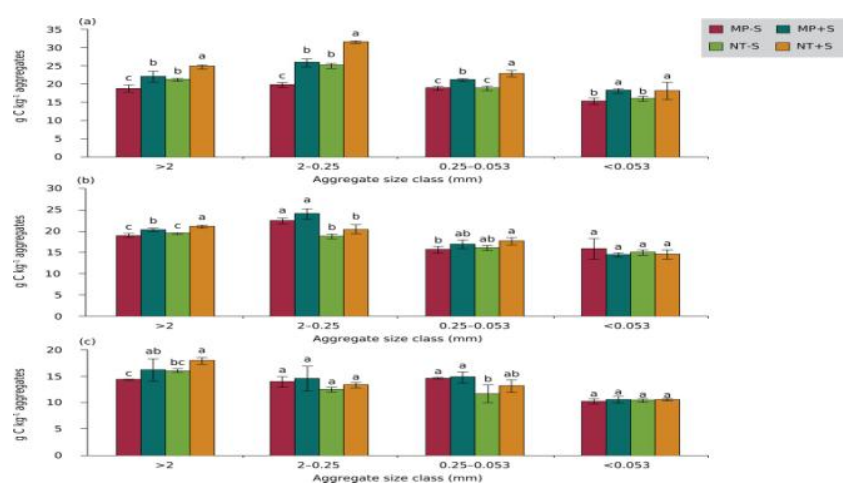

(a)

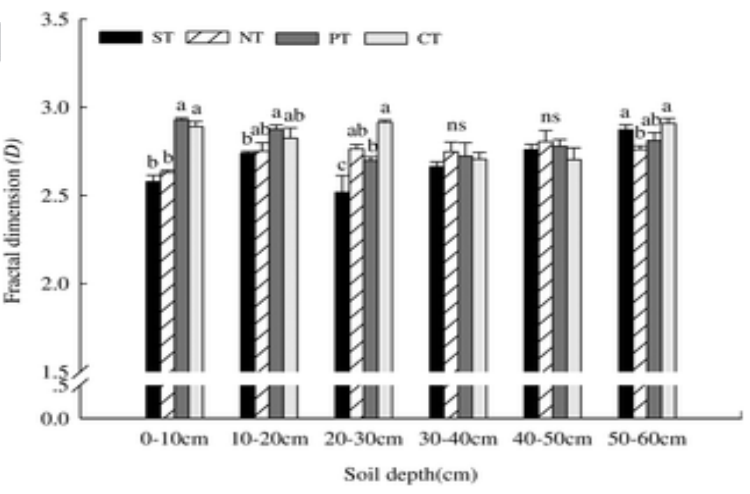

(b)

Fig.3a\&b Effects of cropping systems on the distribution of aggregate size classes at the 0-20 and 20-40 cm depths [Source: Chu et al., 2016] and Total water stable aggregates (a), mean water stable aggregates (b), aggregate carbon content (c), aggregate nitrogen content (d) and soil aggregate carbon weight [ Source: Anders et al., 2010]..
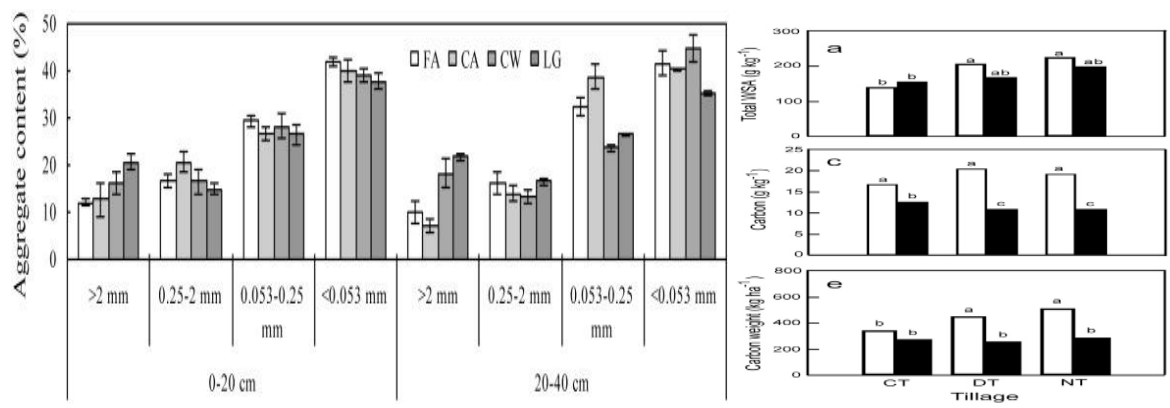

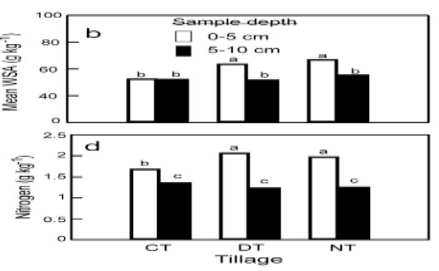


Fig.4 Mean weight diameter (MWD) of soil aggregates (a), Soil aggregate stability (b), carbon preservation capacity of different soil aggregates $0-15 \mathrm{~cm}$ (c) and carbon preservation capacity of different soil aggregates 15-30 cm (d) [ Source: Song et al., 2016]

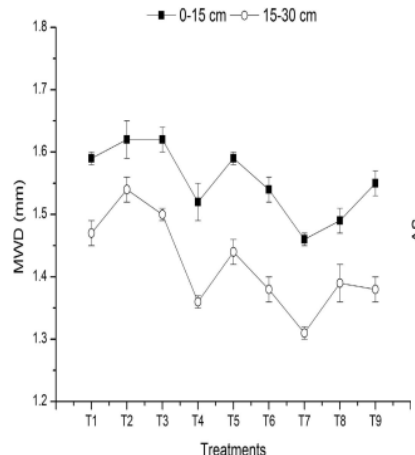

(a)

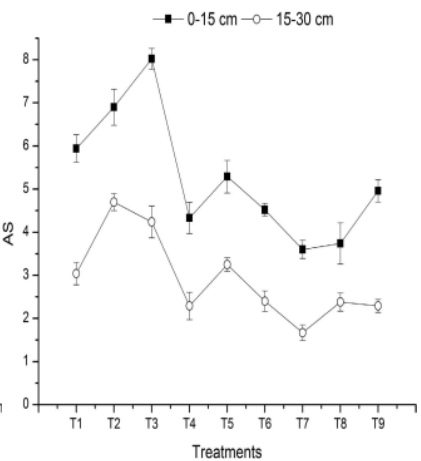

(b)

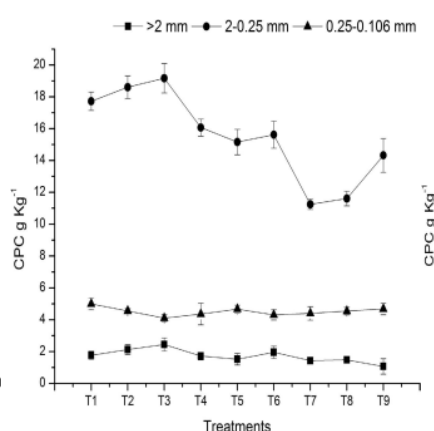

(c)

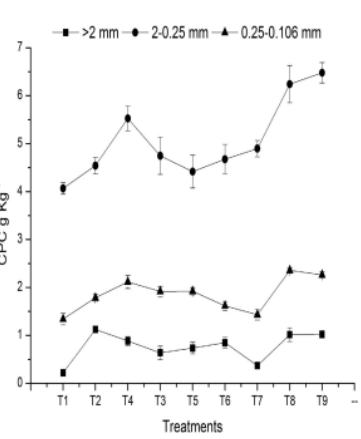

(d)

Fig.5a,b\&c Distribution of water-stable aggregates on a sand free soil (a) and Total soil organic $\mathrm{C}$ (SOC), fine C (.53 mm), and particulate organic C (POC) (53-2000 mm) concentrations on a sand-free basis from 0-5 cm (b) [ Source: Devine et al., 2014] and c. Aggregate-size distribution as determined by wet sieving for (a) the $0-15-\mathrm{cm}$ and (b) the 15-30-cm layers under conventional tillage with residue removal (CT), shallow tillage with residue cover (ST), and notillage with residue cover (NT) [Source Chen et al., 2009]

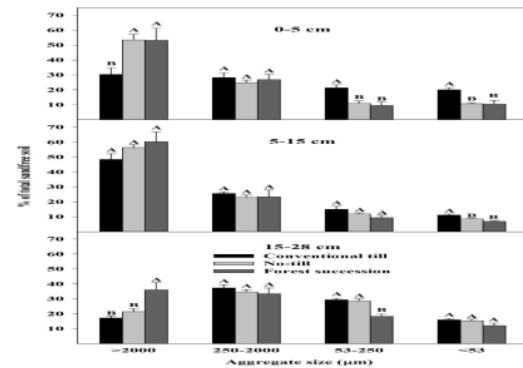

(a)

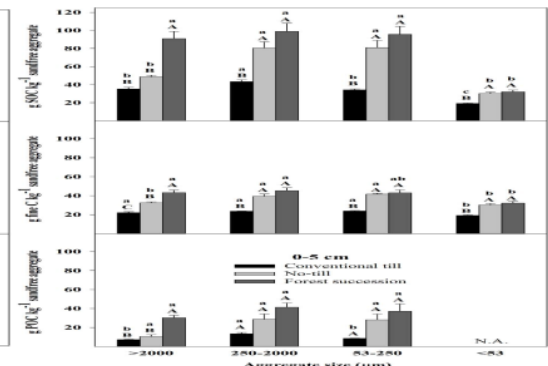

(b)

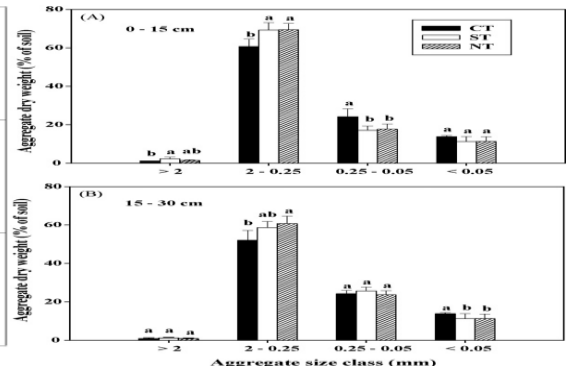

(c)

Fig.6a\&b Mean weight diameters (A) and geometric mean diameters (B) of soil from two depths among aggregate-size fractions under conventional tillage with residue removal (CT), shallow tillage with residue cover (ST), and no-tillage with residue cover (NT) [Source Chen et al., 2009] and Aggregate-size distribution as determined by wet sieving for (a) the $0-15-\mathrm{cm}$ and (b) the 15 $30-\mathrm{cm}$ layers under conventional tillage with residue removal (CT), shallow tillage with residue cover (ST), and no-tillage with residue cover (NT) [Source Chen et al., 2009]
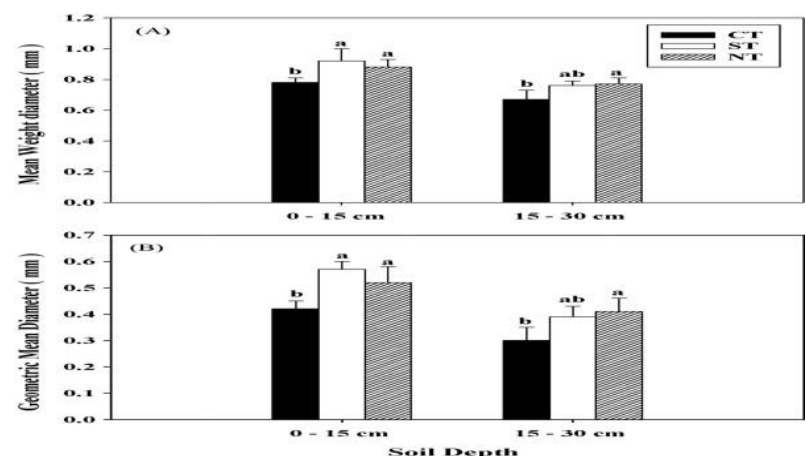

(a)

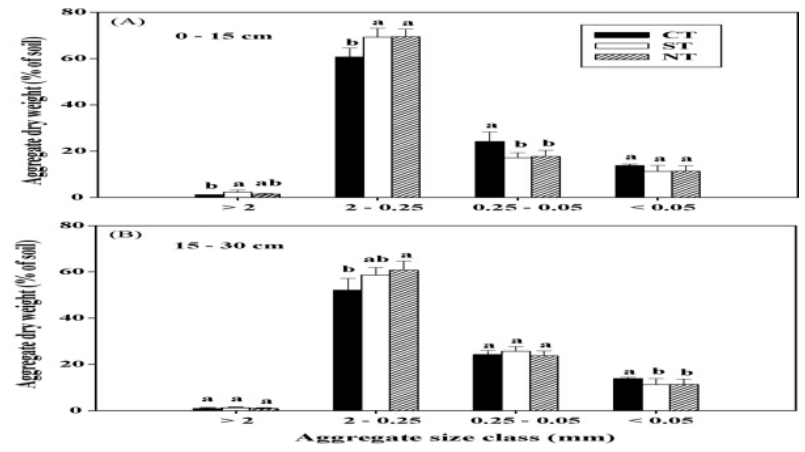

(b) 
Fig.7a\&b Soil organic C ( $\mathrm{g} \mathrm{kg}-1$ of bulk soil) as influenced by tillage practices at (a) rice and

(b) wheat harvest [Source: Kumari, M. et al., 2011] and Intra-aggregate particulate organic matter (iPOM) C ( $\mathrm{g} \mathrm{kg}-1$ of sand-free aggregates) in aggregate-size fractions at the 0 - to 5-cm soil depth at (i) rice and (ii) wheat harvest. '(a)' and '(b)' in legend refer to coarse (0.25-2 mm) and fi ne $(0.053-0.25 \mathrm{~mm}) \mathrm{iPOM}$ in the respective size of aggregates [Source: Kumari, M. et al., 2011]

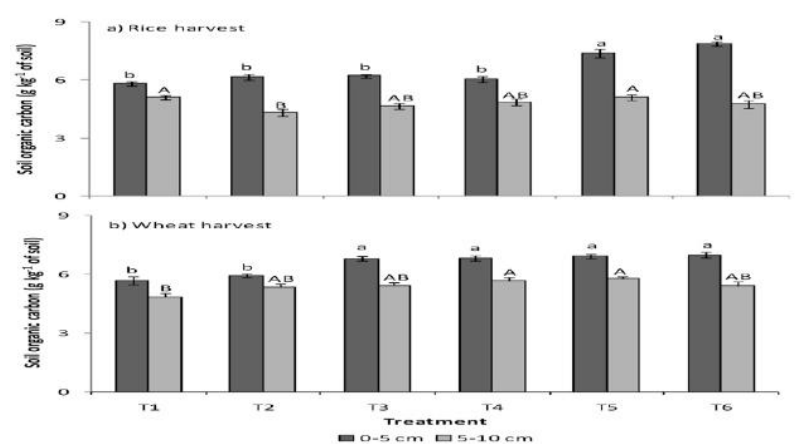

(a)

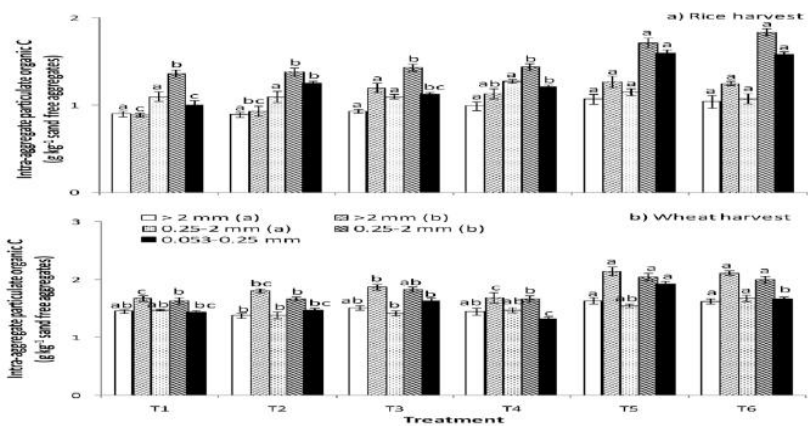

(b)

Fig.8a,b\&c Effects of long term integrated nutrient management practices on aggregate associated carbon in the soil [Source: Mazumdar et al., 2015], Organic C content (g kg-1 soil) of the SOC fractions: coarse iPOM, fine iPOM, mSOM, and free LF of small macro-aggregates and micro-aggregates in the 0-20 cm and 20-40 cm soil layers under MR-WR, MR, and WR [Source: Zhao et al., 2018] and Soil organic carbon (SOC) and nitrogen content (g kg-1) of sandfree aggregates from two depths under conventional tillage with residue removal (CT), shallow tillage with residue cover (ST), and no-tillage with residue cover (NT) [Source: Naresh et al., 2017]

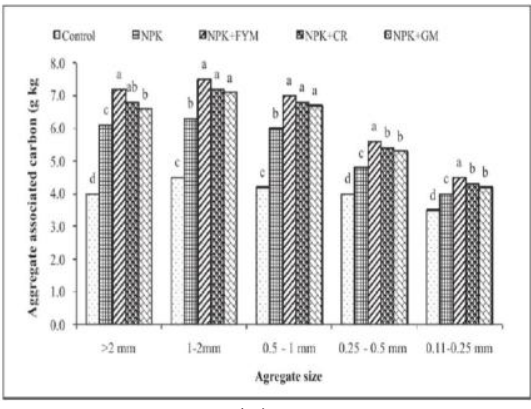

(a)

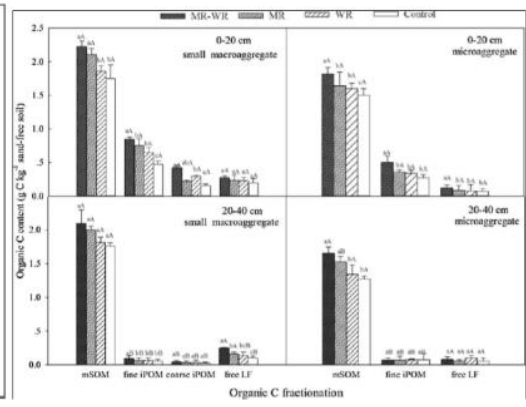

(b)

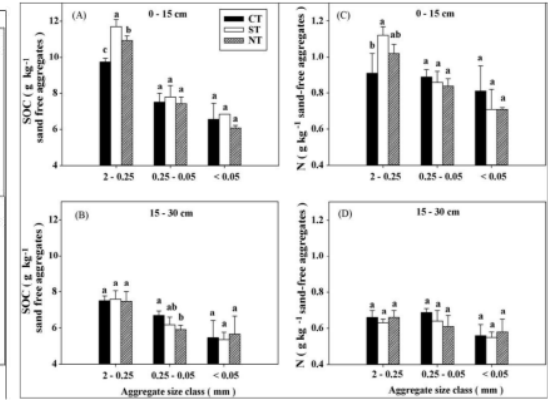

(c)

Fig.9 Dynamic changes of carbon fractions [Source: Gu et al., 2016]

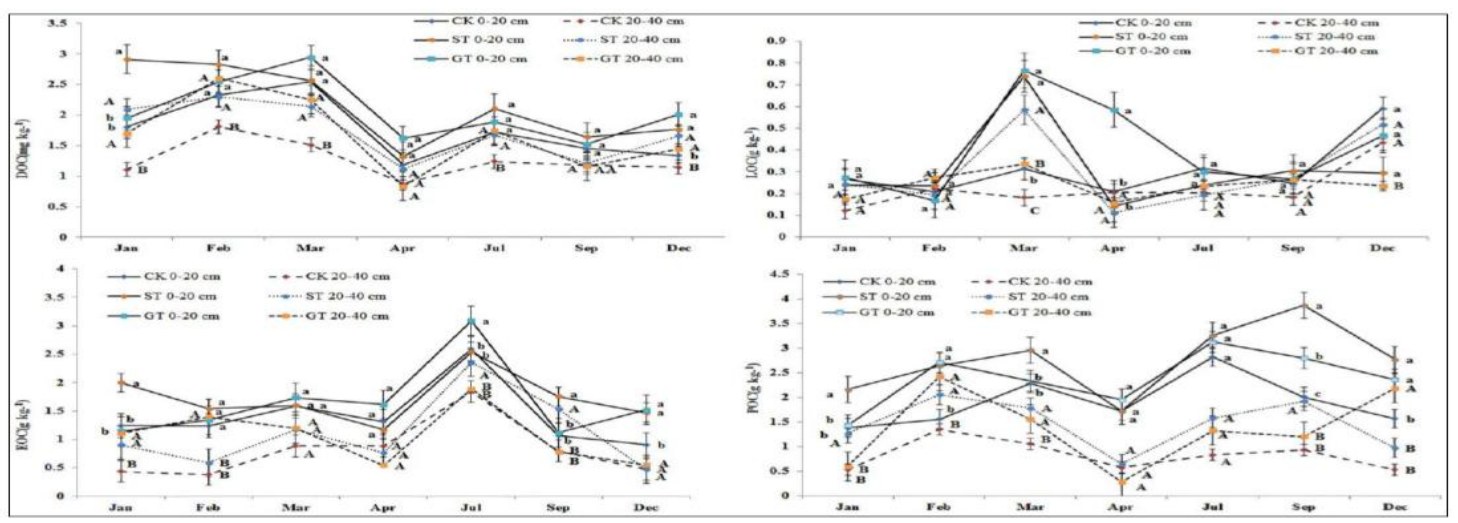


Fig.10a\&b Distribution (\%) of water-stable aggregates with different sizes in different soil layers as influenced by tillage treatments. (a) $0.00-0.05 \mathrm{~m}$; (b) $0.05-0.20 \mathrm{~m}$; (c) $0.20-0.30 \mathrm{~m}$. MP-S: moldboard plow without straw; MP+S: moldboard plow with straw; NT-S: no-tillage without straw; NT+S: no-tillage with straw [Source: Ou et al., 2016] and Aggregate-associated SOC concentration in different layer intervals as influenced by tillage treatments. (a) 0.00-0.05 m; (b) 0.05-0.20 m; (c) 0.20-0.30 m. MP-S: moldboard plow without straw; MP+S: moldboard plow with straw; NT-S: no-tillage without straw; NT+S: no-tillage with straw [Source: Ou et al., 2016]

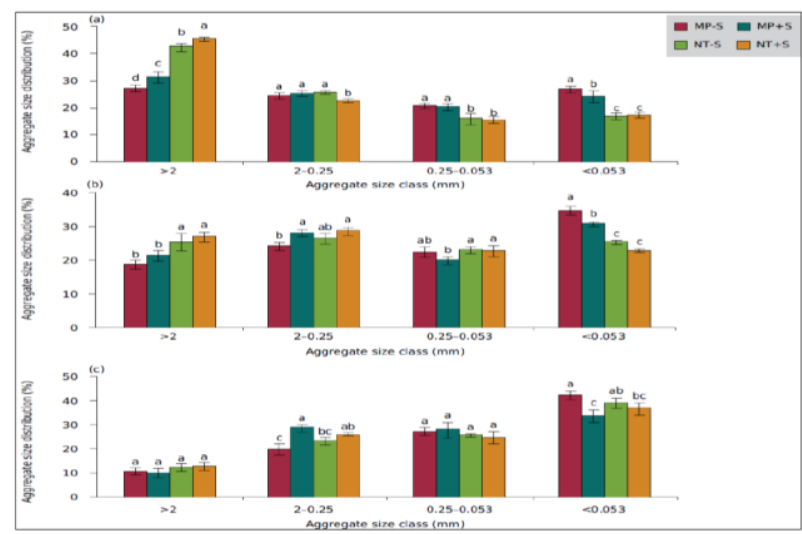

(a)

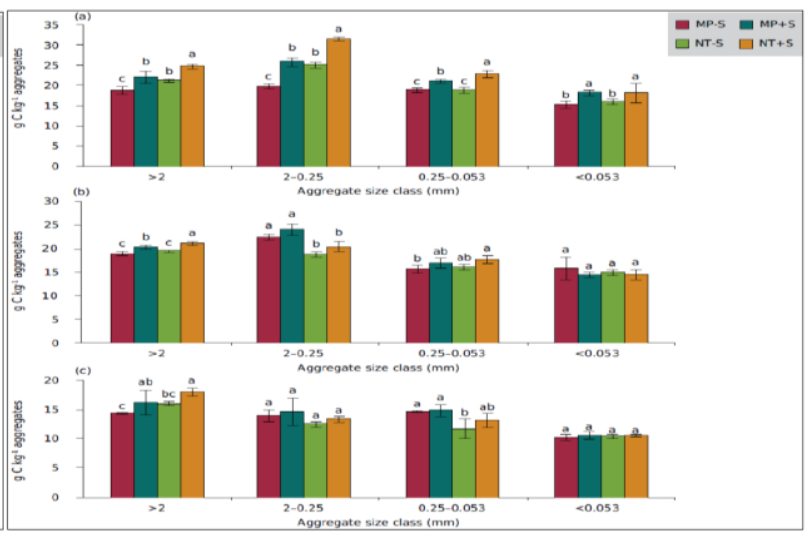

(b)

Fig.11a,b\&c Soil OC stocks (a) and sequestrations (c) in each restoration stage, and soil OC stocks (b) and sequestrations (d) changes over the time since land-use change [Source: Deng et al., 2016], Rates of total soil OC stocks increase in each restoration stage (a) and changes over time (b) since land-use change [Source: Deng et al., 2016] and Changes in the proportions of new and old soil OC in soils with time since land-use change [Source: Deng et al., 2016]

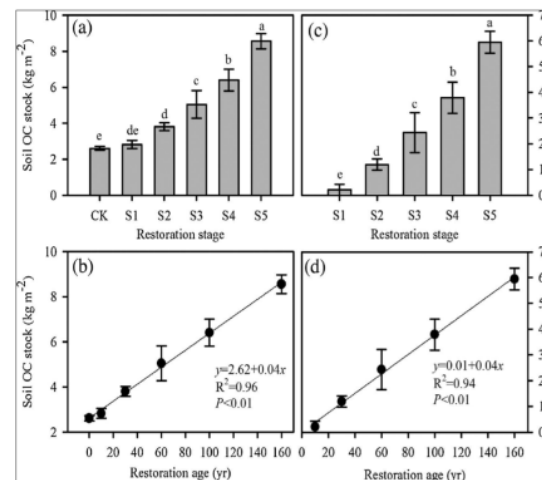

(a)

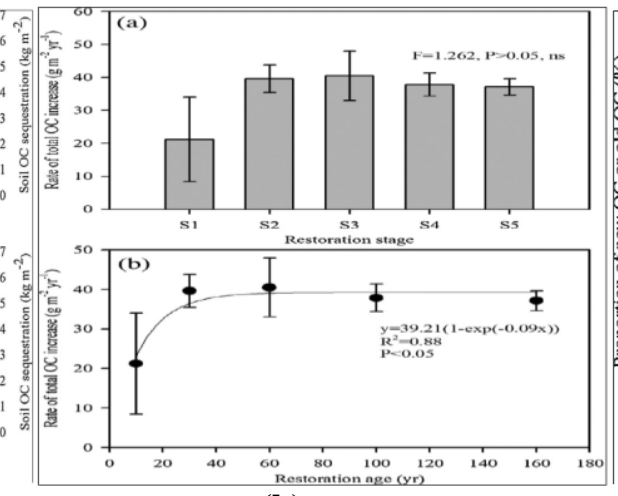

(b)

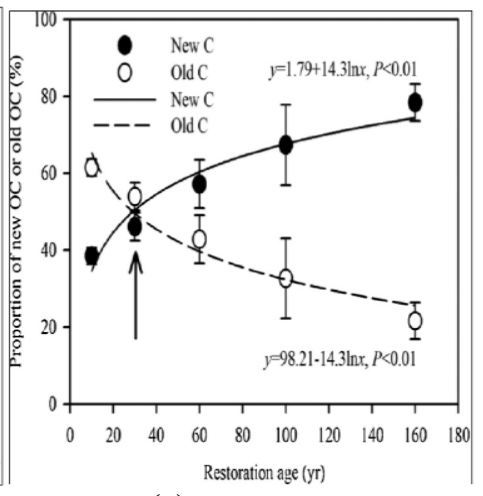

(c)
The rates of soil OC sequestrations increased in the early 30 years, and then slightly decreased along with vegetation restoration, but the trend was not significant over the restoration age (Fig.11b). Among the different restoration stages, the rates showed nonsignificant differences (Fig.11b), but the values were higher in the early stage $(<30$ year) of vegetation restoration than the latter (Fig.11b). An et al., (2009) also found that soil nutrients and microbial properties all increased very quickly in the earlier vegetation restoration stage lasting as long as 23 years, and were stable without significant 
fluctuation in later years. Soil microorganisms increase following the availability of increased organic inputs from vegetation (Jangid et al., 2011). Soil nutrients and organic matter probably increase following increases in soil microbes and may explain the observed changes in soil carbon sequestration rates. The proportions of old soil OC decreased, while the proportions of new soil $\mathrm{C}$ increased significantly with time since land-use change (Fig.11c). This indicated that time since land-use change was an important factor determining the proportions of new and old OC in soils (Zhang et al., 2015).

The accumulation of $\mathrm{C}$ in soil was related to soil aggregation and the distribution of $\mathrm{C}$ in aggregates. By significantly improving soil aggregation and associated $\mathrm{C}$ content, the potential of conservation tillage (CT) systems in a rice-wheat rotation for enhancing $\mathrm{C}$ storage was noted. The differences were prominent mostly in the top $(0-5-\mathrm{cm})$ soil layer, which is the most disturbed layer under a conventional-tillage system. In a rice-wheat rotation, being highly tillage-intensive, the losses of $\mathrm{C}$ from the surface soil can partially be reversed or organic $\mathrm{C}$ pools in the soil conserved through the adoption of ZT or alternate resource-conserving technologies such as transplanted rice on furrow irrigated raised beds followed by wheat on the same beds, which offer less physical disturbance to soils. Conservation tillage systems, especially no-till, increased the proportion of macroaggregates $(>250 \mu \mathrm{m})$, which was attributed to higher soil organic $\mathrm{C}$ level and less mechanical disturbance as compared with MP. The NT and RT treatments also increased aggregate size in the $0-10 \mathrm{~cm}$ depth, indicating that conservation tillage improved soil structure quality. Increase in SOC concentration with conservation tillage was partly responsible for the increased macroaggregation near the soil surface. The adoption of NT and RT practices increased the aggregate $\mathrm{C}$ concentration for all aggregate size fractions in the $0-10 \mathrm{~cm}$ depths.

\section{References}

Anders, M.M., Beck, P.A., Watkins, B.K., Gunter, S.A., Lusby, K.S. and Hubbell, D.S. 2001). Soil Aggregates and their Associated Carbon and Nitrogen Content in Winter Annual Pastures. Soil Sci. Soc. Am. J. 74:1339-1347.

Angers, D.A. and Chenu, C. 1997. Dynamics of Soil Aggregation and C Sequestration. Soil Processes and the Carbon Cycle, CRC Press, Boca Raton. 199-206.

An, S., Mentler, A., Mayer, H. and Blum, W.E.H. 2010. Soil aggregation, aggregate stability, organic carbon and nitrogen in different soil aggregate fractions under forest and shrub vegetation on the Loess Plateau, China. Catena. 81: 226-233.

An, T, Schaeffer S, Zhuang J, Radosevich M, Li SY, Li H, Pei JB, and Wang JK. 2015. Dynamics and distribution of 13C-labeled straw carbon by microorganisms as affected by soil fertility levels in the black soil region of Northeast China. Biol. Fertil. Soils. 51:605-613.

Anders, M.M., Brye, K.R., Olk, D.C. and Schmid, B.T. (2012). Rice rotation and tillage effects on soil dynamics. Soil sci soc Am J 76: 994-1004.

Bajracharya, R.M., Lal, R., Kimble, J.M., Follet, R.F. and Stewart, B.A. (1997). Soil Organic Carbon Distribution in Aggregates and Primary Particle Fractions as Influenced by Erosion Phases and Landscape Positions Soil Processes and the Carbon Cycle, CRC Press, Boca Raton. 353-368.

Baver, L. D. and Gardner, W. H. 1972. Soil physics. Wiley Eastern Limited, New Delhi. pp. 498.

Beare, M.H., Hendrix, P.F. and Coleman, D.C. 1994. Water- Stable Aggregates and Organic Matter Fractions in Conventional 
and No-Tillage Soils. Soil Sci Soc Am J 58 (3) 777-786.

Beare, M.H., Cabrera, M.L., Hendrix, P.F. and Coleman, D.C. 1994. Aggregateprotected and unprotected organic-matter pools in conventional-tillage and notillage soils. Soil Sci Soc Am J 58: 787795.

Blanco-Canqui, H., and and Lal, R. 2004. Mechanisms of Carbon Sequestration in Soil Aggregates. Critical Rev Plant Sci. 23(6):481-504

Bronick, C.J. and Lal, R. 2005. Soil structure and management: A review. Geoderma 124:3-22.

Cambardella, C.A. and Elliott, E.T. (1993). Methods for Physical Separation and Characterization of Soil Organic Matter Fractions. Geoderma 56 (4): 449-457.

Cambardella, C.A. and E.T. Elliott. (1993). Carbon and nitrogen distribution in aggregates from cultivated and native grassland soils. Soil Sci. Soc. Am. J. 57:1071-1076.

Campbell, C.A., Moulin, A.P., Curtin, D., Lafond, G.P. and Smith, L.T. 1993. Soil aggregation as influenced by cultural practices in Saskatchewan: I. Black Chernozemic soils. Can. J. Soil Sci. 73:579-595.

Carter, M.R. 1992. Influence of Reduced Tillage Systems on Organic Matter, Microbial Biomass, Macro-Aggregate Distribution and Structural Stability of the Surface Soil in a Humid Climate. Soil Tillage Res 23 (4): 361-372.

Castro, F., Lourenço, C., A., Guimarães, M.F. and Fonseca, I.C.B. 2002. Aggregate stability under different soil management systems in a red latosol in the state of Paraná, Brazil. Soil Tillage Res. 65: 4551.

Castro, M.M.T., Alvesb, M.C. and WhalenC, J. 2004. Effect of tillage practices on aggregate size distribution in a latossolo vermelho (oxisol) of sp-Brazil. International Soil Conservation Organisation Conference - Brisbane. Paper No. 773.
Causarano, H. J. 2008. Soil organic carbon fractions and aggregation in the Southern Piedmont and Coastal Plain. Soil Sci. Soc. Am. J. 72: 221-230.

Chen, H., Hou, R., Gong, Y., Li, H., Fan, M. and Kuzyakov, Y. 2009. Effects of 11 years of conservation tillage on soil organic matter fractions in wheat monoculture in Loess Plateau of China. Soil Tillage Res 106: 85-94.

Choudhury, S., Gupta, Srivastava, S., Singh, R., Chaudhari, S.K., Sharma, D.K. and Singh S.K. 2014. Tillage and residue management effects on soil aggregation, organic carbon dynamics and yield attribute in rice-wheat cropping system under reclaimed sodic soil. Soil Tillage Res. 136:67-83.

Chu, J., Zhang, T., Chang, W., Zhang, D., Zulfiqar, S., Fu, A. and Hao, Y. 2016. Impacts of cropping systems on aggregates associated organic carbon and nitrogen in a semiarid highland Agroecosystem. PLOS ONE 11(10): 16-50.

Denef, K., Six, J., Bossuyt, H., Frey, S.D., Elliott, E.T., Merckx, R. and Paustian, K. 2001 Influence of dry-wet cycles on the interrelationship between aggregate, particulate organic matter, and microbial community dynamics. Soil Biol Biochem. 33:1599-611.

Deng L, Wang K, Tang Z, and Shangguan Z. 2016. Soil organic carbon dynamics following natural vegetation restoration: Evidence from stable carbon isotopes (613C). Agric Ecosyst Environ. 221: 235244.

Devine, S., Markewitz, D., Hendrix, P. and Coleman, D. 2014. Soil Aggregates and Associated Organic Matter under Conventional Tillage, No-Tillage, and Forest Succession after Three Decades. PLOS ONE 9 (1): 84-98.

Elliott, E.T. 1986. Aggregate Structure and Carbon, Nitrogen and Phosphorus in Native and Cultivated Soils Soil Sci Soc Am J 50 (3): 627-633.

Franzluebbers, A.J. 2002. Soil organic matter stratification ratio as an indicator of soil 
quality. Soil Tillage Res. 66: 95-106.

Garcia, R.A. and Rosolem, C.A. (2010). Aggregates in a Rhodic Ferralsol under no-tillage and crop rotation. Pesq Agropec Bras. 45:1489-98.

Gu C, Li Y, Mohamed I, Zhang R, Wang X, Nie X, Jiang M, and Margot B. 2016. Dynamic Changes of Soil Surface Organic Carbon under Different Mulching Practices in Citrus Orchards on Sloping Land. PLoS ONE. 11(12):e0168384. doi:10.1371/ journal.pone.0168384

Hendrix, P.F., Franzluebbers, A.J. and McCracken, D.V. (1998). Managements effect on carbon accumulation and loss in soils of the southern Appalachian Piedmont of Georgia. Soil tillage Res 47: 245-251.

Jacobs, A., Rauber, R. and Ludwig, B. 2009. Impact of reduced tillage on carbon and nitrogen storage of two Haplic Luvisols after 40 years. Soil Tillage Res 102:158164

Jangid K, Williams MA, Franzluebbers AJ, Schmidt TM, and Coleman DC. 2011. Land-use history has a stronger impact on soil microbial community composition than aboveground vegetation and soil properties. Soil Biol. Biochem. 43:21842193.

Jastrow, J.D., Boutton, T.W. and Millar, R.M. 1996. Carbon Dynamics of AggregateAssociated Organic Matter Estimated by Carbon-13 Natural Abundance. Soil Sci Soc Am J 60 (3): 801-807.

Jiang $\mathrm{X}, \mathrm{Hu} \mathrm{Y}$, Bedell $\mathrm{JH}$, Xie D, and Wright AL. 2011. Soil organic carbon and nutrient content in aggregate-size fractions of a subtropical rice soil under variable tillage. Soil Use Manage. 27: 2835.

Kay, B.D. 1990. Rates of change of soil structure under different cropping systems. Adv. Soil Sci. 12:1-52.

Kemper, W.D. and Chepil, W.S. 1965. In: Black, C.A. (Ed.), Size Distribution of Aggregation. Methods of Soil Analysis. Am Soc Agron, pp. 499-510.
Kong, A.Y., Six, J., Bryant, D.C., Denison, R.F. and Kessel, C.V. 2005. The Relationship between Carbon Input, Aggregation, and Soil Organic Carbon Stabilization in Sustainable Cropping Systems. Soil Sci Soc Am J 69 (4): 1078-1085.

Kumari, M., Chakraborty, D., Gathala, M.K., Pathak, H., Dwivedi, B.S., Tomar, R.K., Garg, R.N., Singh, R., and Ladha, J.K. 2011. Soil Aggregation and Associated Organic Carbon Fractions as Affected by Tillage in a Rice-Wheat Rotation in North India. Soil Sci. Soc. Am. J. 75:560567

Lal, R. 2004. Soil carbon storage impact on global climate change and food security. Science 304: 1623-1627.

Li, L., Zhang, X., Zhang, P., Zheng, J. and Pan G. 2007. Variation of organic carbon and nitrogen in aggregate-size fractions of a paddy soil under fertilization practices from Tai Lake region, China. J. Sci. Food Agric. 87:1052-1058.

Liu Y, Tao Y, Wan KY, Zhang GS, Liu DB, Xiong GY, and Chen F. 2012. Runoff and nutrient losses in citrus orchards on sloping land subjected to different surface mulching practices in the Danjiangkou Reservoir area of China. Agric Water Manag. 110:34-40.

Madari, B.E., Machado, P., Torres, E., Andrade, A.G. and Valencia, L.I.O. 2005. No tillage and crop rotation effects on soil aggregation and organic carbon in a Rhodic Ferralsol from southern Brazil. Soil Tillage Res. 80:185-200.

Mazumdar SP, Kundu DK, Nayak AK, and Ghosh D. 2015. Soil Aggregation and Associated Organic Carbon as Affected by Long Term Application of Fertilizer and Organic Manures under Rice-Wheat System in Middle Gangetic Plains of India. J Agric Phy. 15 (2):113-121.

Mikha, M.M. and Rice, C.W. 2004. Tillage and manure effects on soil aggregate associated carbon and nitrogen. Soil Sci. Soc. Am. J. 68:809-816.

Naresh RK, Timsina J, Bhaskar S, Gupta RK, Singh AK, Dhaliwal SS, et al., 2017. 
Effects of Tillage, Residue and Nutrient Management on Soil Organic Carbon Dynamics and its Fractions, Soil Aggregate Stability and Soil Carbon Sequestration: A Review. EC Nutrition (12) 2:53-80.

Naresh RK, Singh SP, Gupta RK, Arvind Kumar, Ashok Kumar, Rathore RS et al., 2018.Long term effects of tillage and residue management on soil aggregation, soil carbon sequestration and energy relations under rice-wheat cropping system in Typic Ustochrept soil of Uttar Pradesh. J Pharmaco Phytochem. 7(1):237-247.

Oades, J.M., and A.G. Waters. 1991. Aggregate hierarchy is soils. Aust. J. Soil Res. 29:815-828.

Ou, H.P., Liu, X.H., Chen, Q.S., Huang, Y.F., He, M.J., Tan, H.W., Xu, F.L., Li, Y.R., and $\mathrm{Gu}, \mathrm{M} . \mathrm{H}$. 2016. Water-Stable Aggregates and Associated Carbon in a Subtropical Rice Soil Under Variable Tillage. Rev Bras Cienc Solo. 40: 145150.

Paustian, K., Collins, H.P. and Paul, E.A. 1997. Management control in soil carbon. In EAPaul et al., (ed) Soil organic matter in temperate ecosystem: Long term experiment in North America CRC Press Boca Raton, FL: 15-49.

Post WM, and Kwon KC. 2000. Soil carbon sequest ration and land use change: processes and potential. Glob Change Biol. 6 (3):317 \pm 327.

Roberson, E.B. 1991. Extracellular polysaccharide production by soil bacteria; Environmental control and significance in agricultural soils. Ph.D. Thesis. Univ. of California, Berkeley.

Saha, Debasish, Kukal SS, and Bawa SS.2014. Soil organic carbon stock and fractions in relation to land use and soil depth in the degraded shiwaliks hills of lower Himalayas. Land Degrad. Dev. 25:407416.

Sainju, U.M. 2006. Carbon and nitrogen pools in soil aggregates separated by dry and wet sieving methods. Soil Sci. 172:937-
949.

Schutter, M.E. and Dick, R.P. 2002. Microbial community profiles and activities among aggregates of winter fallow and cover cropped soil. Soil Sci. Soc. Am. J. 66:142153.

Shaver, T.M., Peterson, G.A., Ahuja, L.R., Westfall, D.G., Sherrod, L.A. and Dunn, G. 2002. Surface soil physical properties after twelve years of dry land no-till management. Soil Sci. Soc. Am. J. 66:1296-1303.

Six, J., Elliott, E.T. and Paustian, K. (1998). Aggregate and soil organic matter dynamics under conventional and no tillage systems. Soil Sci Soc Am J 63: 1350-1358.

Six, J., Elliott, E.T., Paustian, K. and Doran, J.W. 1998. Aggregation and Soil Organic Matter Accumulation in Cultivated and Native Grassland Soils. Soil Sci Soc Am J 62 (5): 1367-1377.

Six, J., Elliott, E.T. and Paustian, K. (2000). Soil Macro aggregate Turnover and Micro aggregate Formation: A Mechanism for $\mathrm{C}$ Sequestration under No-Tillage Agriculture. Soil Biol Biochem 32 (14): 2099-2103.

Six, J., Paustian, K., Elliott, E.T. and Combrink, C. 2000. Soil structure and organic matter: I. Distribution of aggregate size classes and aggregate-associated carbon. Soil Sci. Soc. Am. J. 64:681-689.

Six, J., Conant, R.T., Paul, E.A. and Paustian, K. 2002. Stabilization mechanisms of soil organic matter: implications for Csaturation of soils. Plant Soil 241: 155176.

Six, J., Bossuyt, H., De, G. S. and Denef, K. 2004. A history of research on the link between (micro) aggregates, soil biota, and soil organic matter dynamics. Soil Tillage Res. 79: 7-31.

Souza, E.D., Costa, S., Anghinoni, I., Carvalho, P.C.F., Andrigheti, M.H. and Cao, E.G. (2009). Soil organic carbon and nitrogen stocks in an untilled crop-livestock system under different grazing intensities. R Bras Ci Solo. 33:1829-1836. 
Song, K., Yang, J., Xue, Y., Weiguang, L., Zheng, X. and Pan, J. 2016. Influence of tillage practices and straw incorporation on soil aggregates, organic carbon, and crop yields in a rice-wheat rotation system. Sci Rep 6:36602.

Srinivasarao CH, Venkateswarlu B, Lal R, Singh AK, Vittal KPR, Kundu S, et al., 2012. Long-term effects of soil fertility management on carbon sequestration in a rice-lentil cropping system of the IndoGangetic plains. Soil Sci Soc Am J. 76 (1):168-178.

Stewart C, Plante A, Paustian K, Conant R, and Six J. 2008. Soil Carbon Saturation: Linking concept and measurable carbon pools. Soil Sci Soc Am J. 72:379-392.

Sundquist, E. T. 1993. The Global Carbon Dioxide Budget," Science 259 (5097): 936-961.

Tang XY, Liu SG, Liu JX, and Zhou GY. 2010. Effects of vegetation restoration and slope positions on soil aggregation and soil carbon accumulation on heavily eroded tropical land of Southern China. J Soils Sedim. 10:505-513.

Tisdall, J.M. and Oades, J.M. 1982. Organic matter and water-stable aggregates in soils. J Soil Sci. 33:141-163.

Upendra, M., Sainju, Caesar, T., Jalal, T. and Jabro, D. 2009. Carbon and Nitrogen Fractions in Dry land Soil Aggregates Affected by Long-term Tillage and Cropping Sequence. Soil Sci. Soc. Am. J. 73:1488-1495.

Vogelmann ES, Reichert JM, Prevedello J, Awe GO, and Mataix-Solera J. 2013. Can occurrence of soil hydrophobicity promote the increase of aggregates stability? Catena. 110:24-31.

Zhang-liu,DU., Ren, Tu-sheng, Chun-sheng, HU. ZHANG Qing-zhong, and BlancoCanqui, H. 2013. Soil Aggregate Stability and Aggregate-Associated Carbon under Different Tillage Systems in the North China Plain, JIA, 12(11): 2114-2123.

Zhang KR, Dang HS, Zhang QF, and Cheng XL. 2015. Soil carbon dynamics following -use change varied with temperature and precipitation gradients: evidence from stable isotopes. Glob. Change Biol. 21:2762-27.

Zhao YG, Liu XF, Wang ZL, and Hao SW. 2015.Soil organic carbon fractions and sequestration across a 150-yr secondary forest chronosequence on the Loess Plateau, China. Catena. 133:303-308.

Zheng, H., Liu, W., Zheng, J., Luo, Y., Li, R., Wang, H. and Qi, H. 2018. Effect of longterm tillage on soil aggregates and aggregate-associated carbon in black soil of Northeast China. PLOS ONE 13(6): 118.

Zibilske, L.M. and Bradford, J.M. 2007. Soil aggregation, aggregate carbon and nitrogen, and moisture retention induced by conservation tillage. Soil Sci Soc Am J 71: 793-802.

Zotarelli, I., Alves, B.J.R., Urquiaga, S., Torres, E., dos Santos, H.P., Paustian, K., Boddey, R.M. and Six, J. (2005). Impact of tillage and crop rotation on aggregateassociated carbon in two Oxisols. Soil Sci Soc Am J 69: 482-491.

\section{How to cite this article:}

Rajendra Kumar, R.K. Naresh, N.C. Mahajan, S.K. Tomar, M. Sharath Chandra and Sunil Kumar. 2019. Soil Aggregate Stability and Aggregate-Associated Carbon Fractions under Different Tillage Systems of Rice-Wheat Rotation in North India: A Review. Int.J.Curr.Microbiol.App.Sci. 8(06): 1203-1221. doi: https://doi.org/10.20546/ijcmas.2019.806.148 